\title{
Tectonics and paleogeography of the Marajó Basin, northern Brazil
}

\author{
JOÃO B. S. COSTA ${ }^{1}$, YOCITERU HASUI ${ }^{2}$, RUTH L. BEMERGUY ${ }^{3}$, \\ ADILSON V. SOARES-JÚNIOR ${ }^{4}$ and JAVIER M. C. VILLEGAS ${ }^{4}$ \\ ${ }^{1}$ Instituto de Estudos Superiores da Amazônia, 66055-260 Belém, PA \\ ${ }^{2}$ Departamento de Petrologia e Metalogenia, Instituto de Geociências e Ciências Exatas \\ Universidade Estadual Paulista, 13506-900 Rio Claro, SP \\ ${ }^{3}$ Centro de Geociências, Universidade Federal do Pará, 66055-260 Belém, PA \\ ${ }^{4}$ Curso de Pós-Graduação em Geologia e Geoquímica, Universidade Federal do Pará, 66075-900 Belém, PA \\ Manuscript received on June 18, 2001; accepted for publication on February 26, 2002; \\ contributed by YOCITERU HASUI*
}

\begin{abstract}
The Marajó Basin area presents geologic and geomorphologic features chiefly due to the Mesozoic extension and post-Miocene neotectonics. The extension event with an Early and a Late Cretaceous phases originated four sub-basins that constitutes the Marajó Basin, with a thick continental clastic sequence showing marine influence. NW and NNW normal faults and NE and ENE strike-slip faults controlled the basin geometry. The extension, related to the Equatorial Atlantic opening, propagated into the continent along crustal weakness zones of the Precambrian Tumucumaque, Amapá and Araguaia orogenic belts. The neotectonic event is a strike-slip regime which developed transtensional basins filled in by Upper Tertiary shallow marine (Pirabas Formation) and transitional sequences (Barreiras Group), followed by Quaternary fluvial deposits and transitional sequences derived from the Amazon and Tocantins rivers and the Marajoara estuary. The current landscape has a typical estuarine morphology. The coast morphology presents sea-cliffs on transitional Upper Tertiary sequences, while inwards dominate hills sustained by Mid-Pleistocene lateritic crust, with a flat erosive surface at $70 \mathrm{~m}$. In the eastern Marajó Island several generations of paleochannels associated with fluvial-estuarine sequences are recognized, while a fluvial-marine plain is widespread on its western side.
\end{abstract}

Key words: Marajó Basin, structure, evolution, paleogeography, geomorphology.

\section{INTRODUCTION}

Beneath a thick Tertiary sequence in the Marajó Island and adjacent areas there is a large extensional Mesozoic rift system which consists of four major sub-basins (Mexiana to the north, Limoeiro in the center, and Cametá and Mocajuba in the south; Figure 1), evidenced from gravity and magnetic data and detailed seismic interpretation (Rezende and Ferradaes 1971, Schaller et al. 1971, Miller and

Correspondence to: João Batista Sena Costa

E-mail: jbsena@iesam.com.br

* Member of Academia Brasileira de Ciências
Avenius 1986, Carvajal et al. 1989).

Geological and geophysical investigations carried out by Petróleo do Brasil S.A. - PETROBRAS, led to delineate the nature of the main structural features of the basin, linked to the Gondwana breakup and Equatorial Atlantic opening (Ludwig 1964, Aguiar et al. 1966, Lana and Milani 1987). The tectonic evolution is better understood if considering important aspects of plate dynamics, basin geometry and rift kinematics to clarify the development of the distinct structural compartments as well as their heritage from Precambrian structures. 


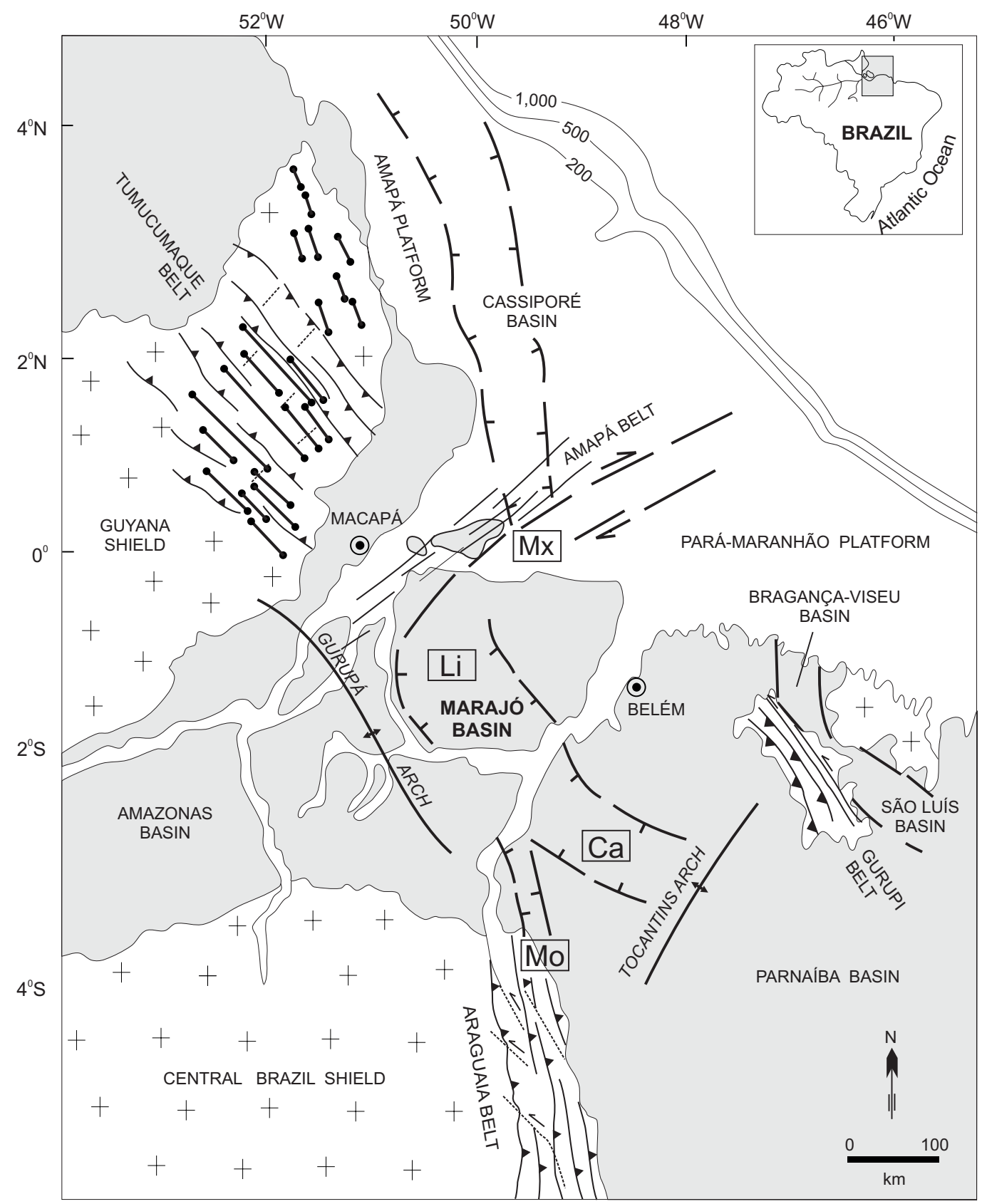

Phanerozoic sedimentary cover

Mesozoic diabase dike

Precambrian crystalline basement and orogenic/shear belts
Li Limoeiro Sub-Basin

$\mathrm{Ca}$ Cametá Sub-Basin

Mo Mocajuba Sub-Basin

Mx Mexiana Sub-Basin $\geqslant$ Strike-slip fault Normal fault Arch $-20^{\circ}$ Isobath $(\mathrm{m})$

Fig. 1 - Simplified tectonic setting of northern Brazil with location of the Marajó Rift and the Precambrian orogenic or shear belts. 
The stratigraphic studies of the Marajó Basin demonstrated that the oldest sedimentary sequence is Paleozoic and is correlated with the Serra Grande Group (Ipú, Tianguá and Jaicós formations) of the Parnaíba Basin, and Trombetas Group (AutásMirim, Pitinga and Manacapuru formations) of the Amazonas Basin (Caputo 1984, Lima 1987, Carvajal et al. 1989) (Figure 2a).

The Marajó Basin filling is composed of a sedimentary pile from Early Cretaceous to the Oligocene, which reaches a thickness of up to $11 \mathrm{~km}$ (Lima 1987). It is divided into the Rift and Post-Rift Sequences (Figure 2a).

The Rift Sequence is formed by two sedimentary units (Miller and Avenius 1986, Carnes et al. 1989, Carvajal et al. 1989). The oldest rift unit could be linked to the early rifting and is only recognized by seismic-stratigraphic studies; it appears to be concordant to the upper one (Carvajal et al. 1989) and it may be Neocomian in age (Carnes et al. 1989). The youngest unit is related to the widening of the basin, and was defined by seismic interpretation and well data samples; it seems to be more homogeneous and is characterized by discontinuous seismic reflectors, and the borehole data indicate deposition in continental to transitional environments, mainly by fluvial and fluvial-deltaic systems (Breves Formation, Itapecuru Formation in the southeastern edge of the Cametá Sub-Basin).

The Rift column includes fanglomerates and coarse sandstones of talus and alluvial fan deposits (Jacarezinho Formation) deposited on the west side of the Mexiana and Limoeiro sub-basins, and along the Cametá Sub-Basin. Avenius (1988) mentions the occurrence of mud-rich silt beds overlying the Breves Formation, probably deposited in large shallow lakes or, alternatively, during a transgression restricted to the Mexiana and Limoeiro sub-basins (Anajás Formation).

The seismic signature of the Post-Rift Sequence is characterized by continuous reflectors formed by alternating layers of clay and silt, evidenced by borehole data from the Mexiana and Limoeiro sub-basins (Lima 1987). This sequence includes two major units (Schaller et al. 1971): the lower one (Limoeiro Formation), Paleocene, is made up of sandstones and subordinate conglomerates and clays; and the upper unit is formed by two packages, deposited conformably over the Limoeiro Formation and derived from deltaic and fluvial environments from Eocene-Pliocene (Marajó Formation) and Quaternary (Tucunaré Formation).

The upper part of the Marajó Formation is correlated to the Pirabas Formation, a shallow water marine sequence, and Barreiras Group, a transitional one, and have been interpreted as linked to the neotectonics, as well as the Quaternary deposits (Tucunaré Formation; Costa et al. 1996).

Neotectonics comprises two sets of structural and morphological features: (1) the MiocenePliocene oldest set includes NW-trending transtensional basins, which resulted from displacement along E-W and NE-SW dextral strike-slip faults; (2) the Pleistocene-Holocene youngest set corresponds also to transtensional structures. In the Miocene the shallow sea ("Pirabas sea') gradually expanded on the continent and reached $150 \mathrm{~km}$ in the northeastern of the Pará State, followed by gradual contraction that allowed the development of the major rivers. These rivers run chiefly parallel to the NESW strike-slip faults that originated from the reactivation of Mesozoic strike-slip faults throughout the Quaternary.

This study, based on prospecting seismic data and geological mapping, is meant to discuss rift architecture, basement control on basin development and landscape evolution related to the opening of the Equatorial Atlantic.

\section{STRUCTURE OF THE MARAJÓ BASIN}

The disposition of Rift depocenters and depocenter controlling faults suggest a half-graben structural/stratigraphic architecture of the Marajó Basin with the sub-basins being separated and segmented by ENE and NE-SW strike-slip faults (Carnes et al. 1989, Lara 1992, Villegas 1994).

The Limoeiro Sub-Basin is NW-trending in the central portion of the Marajó Rift and its southern 

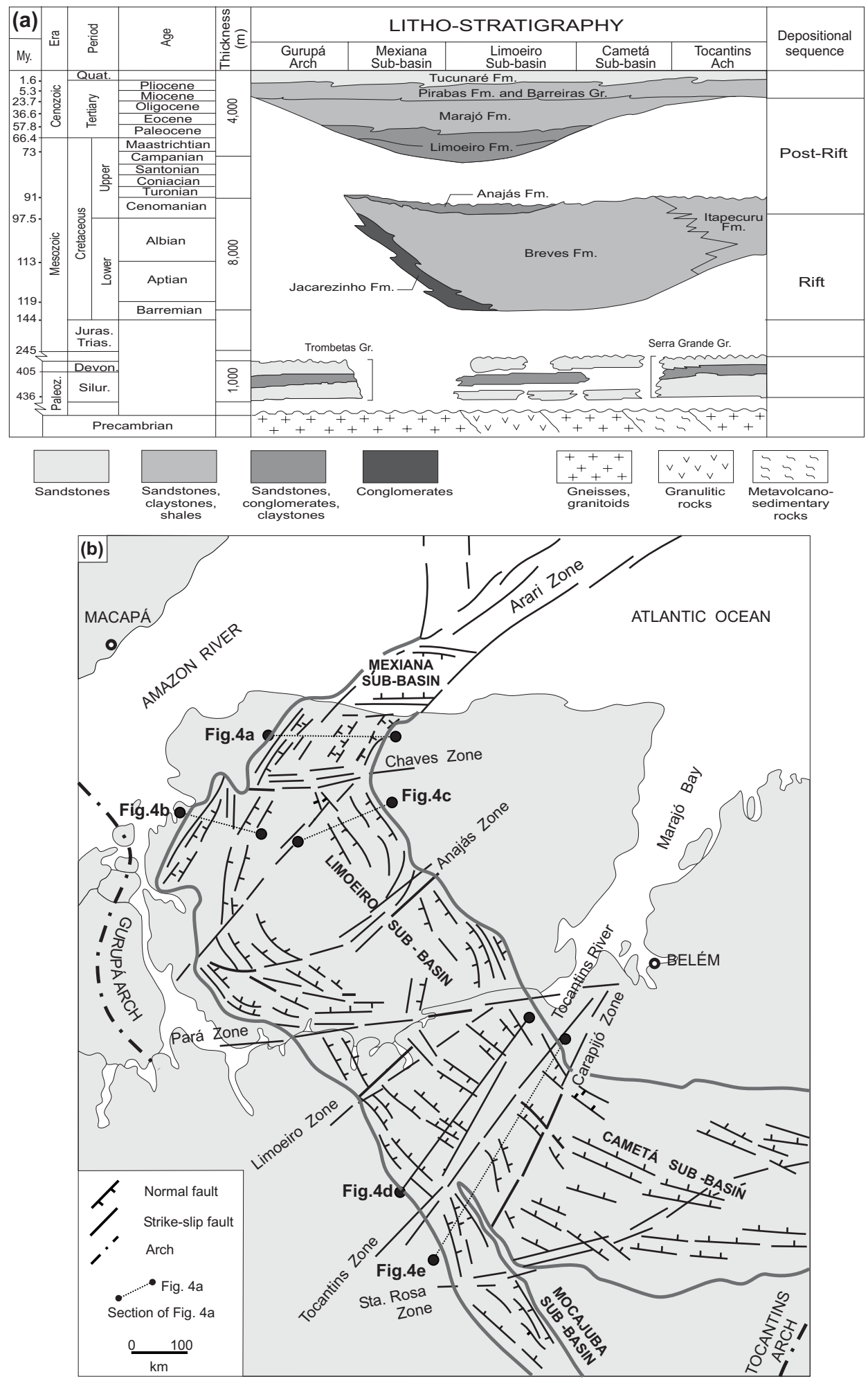

Fig. 2 - Marajó Basin: (a) stratigraphic column (Lima 1987, modified), (b) structure (Villegas 1994). 
and northern boundaries, respectively with Mexiana and Cametá sub-basins, are defined by the Arari and Tocantins strike-slip fault zones (Figure 2b). At the northern end of the Limoeiro Sub-Basin the major normal faults curve northeastward to join the Arari Zone. This sub-basin is divided by minor strikeslip fault zones (Chaves, Anajás, Pará and Limoeiro zones) into five distinct geometric extensional compartments, but their western margins are dominated by large listric normal faults. Some listric main border faults have up to $6 \mathrm{~km}$ basement normal throw (Miller and Avenius 1986, Villegas 1994).

The northwestern portion of the Limoeiro SubBasin have major normal faults which curve northeastward to join the Arari Zone. This sub-basin is formed on the west boundary by a series of linked listric normal faults gently dipping to the southeast and reaching a horizontal position at shallower depths in the basement (Figure 3a). A roll-over is well-developed in the hanging-wall of the detachment fault, defined by rotated blocks of the basement and lower Rift Sequence into the boundary. This large anticline has been partly modified by planar and listric minor faults dipping towards the east. The eastern flank is defined by planar and listric normal faults dipping about $60^{\circ}$ to the west with a rollover on the flat-lying segment of the major fault, at depth, which dies out gradually upwards on the steep planar segment, where dominate an open syncline; these features are associated with a large negative flower structure which affects also the Tertiary pile and is interpreted as the result of dextral strike-slip displacement along the Arari Zone.

The central part of the Limoeiro Sub-Basin is characterized on the west by an imbricated fan of listric normal faults dipping to the east-northeast, that probably become horizontal at a depth of about $15 \mathrm{~km}$, where they should sole into the detachment zone (Figure 3b). Eastwards, there is another listric fan with a series of minor normal faults connecting to the detachment at shallow depths in the basement, which seems to control the development of the youngest Rift Sequence (Figure 2a).This imply that the Limoeiro Sub-Basin underwent high rate of extensional collapse during later rifting, which explains also its greater width (Carnes et al. 1989). A series of listric faults also define the east boundary of this sub-basin, but there are normal faults cutting the entire Rift pile suggesting several pulses of faulting (Figure 3c). There are often high blocks of the basement in the center separating the earlier Rift depocentres near the sub-basin flanks (Figure 3d). This geometry can be followed southeastwards until the Tocantins Zone.

A large isolated NNW-trending basement horst block separates the Cametá from the Mocajuba SubBasin (Figure 2b). The Cametá Sub-Basin displays an asymmetric geometry formed by three smaller depocenters bounded on the west flanks by planar and listric normal faults dipping to the NNE. The rollover is followed on both the basement and filling, but a synform dominates upwards on the steep segments of the major faults. The eastern margin of the sub-basin is dominated by a broad flexural response to the border fault system of the west since the basement and lower Rift Sequence dip away from the boundary (Figure 3e). The geometry throughout the Mocajuba is similar to that of the Cametá Sub-Basin, but it has been suggested that the basement horst block may have been an effective barrier against intrabasinal communication allowing a package of sediments unique to the rest of the basin to be deposited (Carvajal et al. 1989).

The interpretation of potential field data (Bouguer and magnetic maps) and seismic lines has indicated the possible existence of strike-slip zones bounding geometric distinct basin compartments. Most of them display evidence of multi-tectonic phases during the basin evolution, even during the post-rift phase. They played an important role during the normal fault propagation and, likely, controlled the stratigraphy along the axis of the basin, and can be interpreted as transfer faults since they probably accommodated much extension parallel to the extensional axis of the stress field. The usual seismic signatures of these fault zones (Arari, Chaves, Anajás, Pará, Limoeiro, Tocantins, Carapijó and Santa Rosa; Figure 2b) are negative flower struc- 
(a)

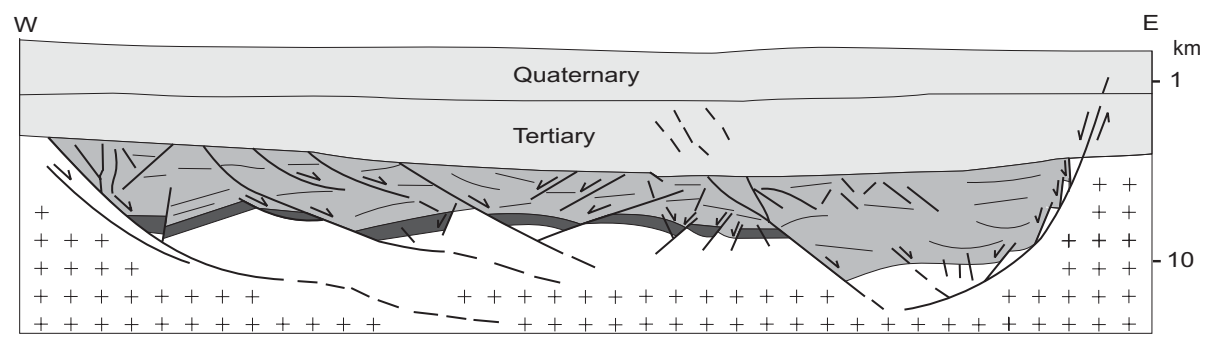

(b)

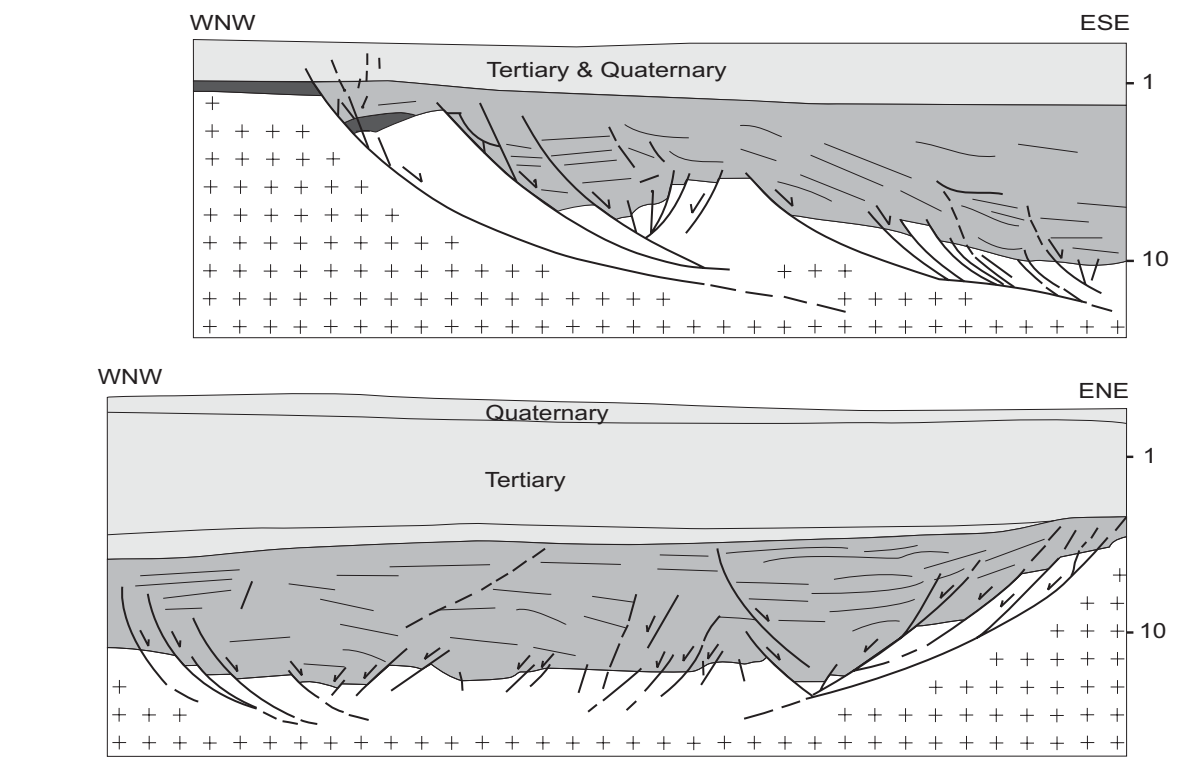

(c)
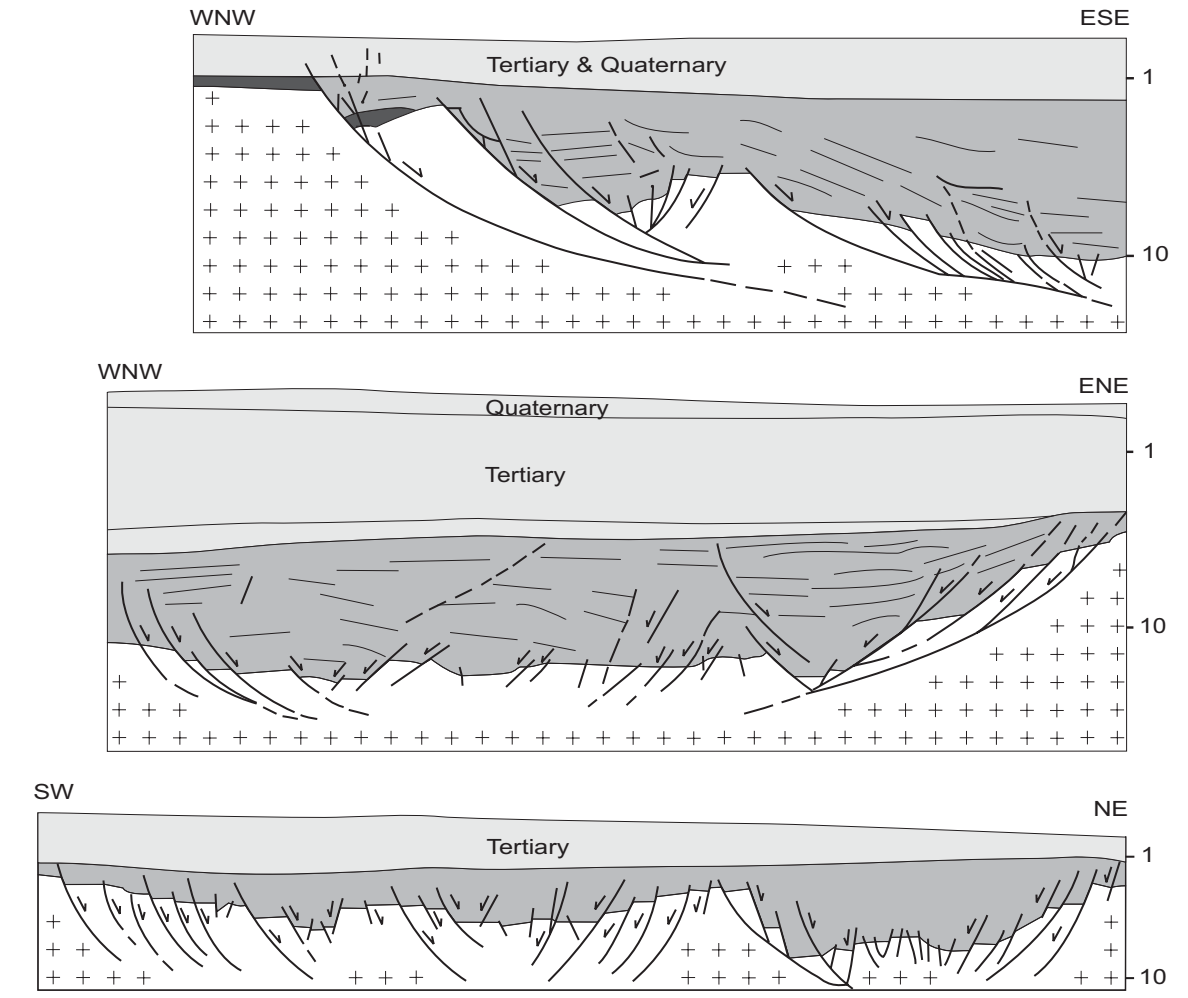

(d)

(e)

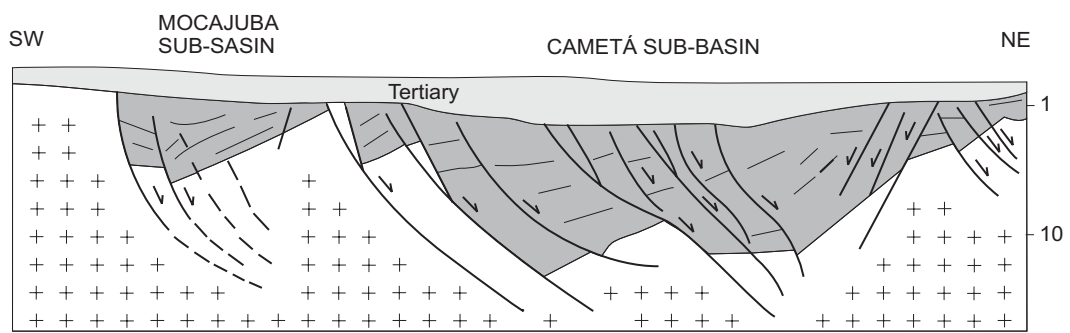

HORIZONTAL SCALES

(a) (b) (c)

(d) (e)

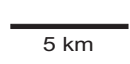

$\overline{10 \mathrm{~km}}$
Post-Rift Sequence

Rift Sequence

Paleozoic Sequence

Precambrian basement

Fig. 3 - Sections-drawing based on seismic interpretations. Limoeiro Sub-Basin: extensional geometry of the northern (a), northwestern (b), northeastern (c) and southern (d) portions. Mocajuba and Cametá sub-basins (e). Location in Figure 3. After Villegas (1994). 
tures, which always cut the Cretaceous pile and can be followed in the basement as steep, discrete zones.

The NE-SW Arari Zone is the most important and extends from the Gurupá Arch towards the offshore. Seismic interpretations indicated that this zone is defined by right-stepping en echélon pairs of overlapping pull-apart sub-basins, of which the Mexiana Sub-Basin is the best known feature, with steep larger border faults on both the east and west margins. The thick Tertiary and Quaternary sedimentary piles deposited in the Mexiana Sub-Basin implies that the Arari Zone remained active throughout the Cenozoic. The available data suggest a multiphase tectonic evolution for the Mexiana Sub-Basin which includes the following steps: (1) transtension during the Cretaceous controlling the deposition of a sedimentary sequence more than $5 \mathrm{~km}$ in thick; (2) transpression probably in the Late Cretaceous inducing chiefly folding; and (3) transtension throughout the Cenozoic originating the Tertiary and Quaternary piles.

The neotectonic setting is defined by a series of linked E-W and NE-SW dextral strike-slip faults and NW-SE normal faults that are grouped into two sets. The oldest set corresponds to NW-SE normal faults that controlled the deposition of the shallow water marine sequence (Pirabas Formation) and transitional sequence (Barreiras Group) in the Upper Tertiary. The youngest set refers to a linked system of strike-slip faults and normal faults forming Pleistocene-Holocene pull-apart basins of variable.

Large slightly rotated blocks, which originated by Upper Pleistocene NW-SE normal faults, dominate in the current landscape of the Marajó Island. The sea-cliffs and paleochannels widespread in the eastern side of the island are closely related to the uplifted blocks, contrasting with large floodplain and dense rectangular drainage pattern of the western side which were developed on subsided blocks. The Marajó Island formed due to the reactivation of the Arari and Tocantins zones which, respectively, captured the lower courses of the Amazonas and Tocantins rivers to the northeast throughout the Quaternary.

\section{GEOPHYSICAL SIGNATURE OF THE MARAJÓ BASIN AND THE SURROUNDING BASEMENT}

The old tectonic setting of the area around Marajo Basin (Figure 1) is characterized by the Araguaia and Tumucumaque orogenic or shear belts which have been interpreted as the result of Precambrian continental collisions (Hasui et al. 1993, Costa and Hasui 1997). The continuity of the Araguaia and Tumucumaque belts, respectively, to north-northwest and southeast, coincides with the area where the Marajó Basin was developed.

The Araguaia Belt trends N-S to NNW-SSE and is composed of meta-sedimentary, mafic and ultramafic rocks (Baixo Araguaia Super-Group), migmatized gneisses and granitoids (Colméia Complex), and high-grade gneisses (Porto Nacional Complex) in the southeastern margin (Hasui and Costa 1990, Hasui et al. 1993). The Tumucumaque Belt, with a NW-SE trend, is exposed from near Macapá to Paramaribo (Suriname) and comprises various rock assemblages: granulitic rocks (mafic granulites, kinzigites, enderbitic and charnockitic gneisses) of the Ananaí and Tartarugal Grande suites; medium-grade tonalitic to trondhjemitic gneisses and granitoids of the Guianense Complex; supracrustal rocks (metavolcanics, iron formations, quartzites, micaschists and metagraywakes) of the Vila Nova Group (João et al. 1979, Lima et al. 1974).

The structural framework of these belts consists of imbricated ductile thrusts systems that are characterized by a pervasive mylonitic foliation dipping to the east and northeast. Along the Araguaia Belt there are also NW to NNW-trending strike-slip shear zones that have been interpreted as lateral ramps that accommodated large amount of compression (Hasui and Costa 1990).

Another belt (Amapá Belt), adjacent and parallel to the Arari Zone, was suggested by potential field data interpretation, but it has not been studied because it is completely covered by Tertiary and Quaternary sedimentary deposits (Hasui et al. 1984).

The Bouguer map for the Marajó Basin and surrounding areas is shown in Figure 4. NW-trending positive and negative gravity anomalies are evident 
and they are not always coincident with the highs and depocentres of the sub-basins. Several magnetic anomalies also exist: the bipolar anomalies are not related to magnetic geological bodies in the basin filling as these are absent, and the linear anomalies are only partly linked to the major fault zones.

As referred above, the Tumucumaque and Araguaia belts are formed by large variety of lithostratigraphic units, which correspond to high and low density/more and less magnetic rocks, besides strike-slip ductile shear zones. This implies that these rock assemblages should display positive and negative gravity anomaly signatures, as well as bipolar and linear magnetic anomalies. Therefore, the geophysical patterns are thought to be mostly due to the rock units and structures of the Precambrian shear belts.

It has been also deduced that the distinct geometric compartments of the Mexiana, Limoeiro, Cametá and Mocajuba sub-basins are closely related to the complex patterns of the ductile thrust systems and strike-slip shear zones of these belts. This is supported by the detachment normal faults dipping to the east and northeast and following the ductile thrust systems, and by the NE-trending anomalies along the Arari Zone coinciding with the strike-slip faulting propagation during the Mesozoic, probably starting with reactivation of shear zones of the Amapá Belt.

In summary, the Precambrian tectonic setting suggests a strong control of the Araguaia and Tumucumaque belts in the geometry of the major faults of the Marajó Basin. However, if the Amapá Belt is confirmed, this feature and the Araguaia Belt are to be regarded as the pre-existing crustal weakness zones for the Mesozoic extensional propagation into the northern Brazil.

\section{PALEOGEOGRAPHY}

During the Paleozoic the Marajó region and surrounding areas interconnected the Amazonas and Parnaíba basins as demonstrated by the remnants of Paleozoic sequences preserved in faulted blocks on the shoulders of the Marajó Rift (Gurupá Arch;
Lima 1987). However, probably by the end of the Paleozoic or Early Mesozoic, the Gurupá high had developed into a well defined horst block with steep normal faults delineating its flanks. The faults of the east flank of the Gurupá Horst form the western margin of the Marajó Rift.

The Marajó Rift may have begun forming in the Early Mesozoic as a result of the separation of the South American, North American and African plates. The early phase of rifting is thought to be of Late Triassic in age with the incipient rifting of the North Atlantic propagated into the South American Plate. This is supported by the plate restoration which shows that the Marajó region is on trend with the early rifting stage of the North Atlantic (Miller and Avenius 1986, Carvajal et al. 1989). A Late Triassic-Early Jurassic age for the initial development of the Marajó Rift coincides also with the magmatic event represented by dyke intrusions (Cassiporé Diabase, 250 to $180 \mathrm{Ma}$; Lima et al. 1974) in Paleozoic sequences and Precambrian basement, but the ages of the propagation of the earliest extensional half-grabens are uncertain, mainly because the early Rift Sequence has not yet been sampled.

Several major seismic packages have been demonstrated throughout the basin. The early Rift Sequence is restricted to the both flanks of the Limoeiro Sub-Basin and the west flanks of Mexiana and Cametá sub-basins, and shows the tendency to thicken into rift faults suggesting distribution in response to active rifting (Carvajal et al. 1989). This interval and the late Rift Sequence are believed to be composed chiefly of fanglomerates derived from the Gurupá Horst partly during the Albian as suggested by continental clastic interval in the upper portion (Figure 5a).

During the entire rift period a major fluvial system probably flowed into Marajó from the west and southeast (Bemerguy and Costa 1991). Some sediments came into the Marajó region from eastern and northern, but these areas are regarded as less important sediment sources at least in the later rift stage because part of the Pará-Maranhão Platform was collapsing due to the spreading of the South At- 


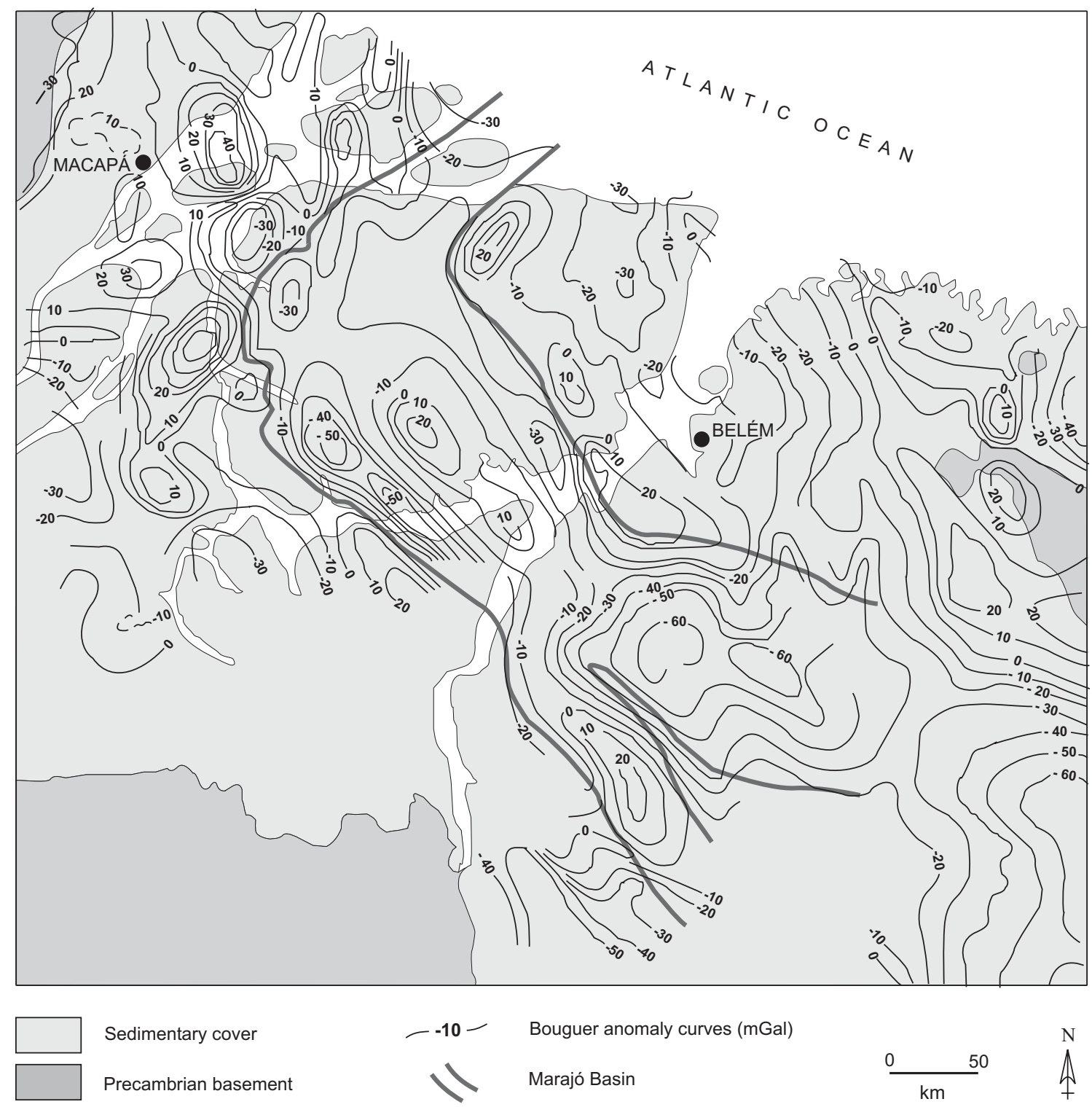

Fig. 4 - Simplified Bouguer anomaly map of the Marajó rift and surrounding areas.

lantic rifting (Figure 5b). Additionally, it must be considered the existence of the drainage divide between Marajó Rift and the young Atlantic Ocean, which has worked as a natural barrier for the development of a large drainage area in the north and east of Marajó region. It must be conceded that the Mexiana Sub-Basin is ideally situated to have received a marine incursion during the latest rift time since the Arari Zone would have been a shorter route to the early North Atlantic and the Marajó region. However, it is proposed here that much of the rift fluvial clastics of the Mexiana Sub-Basin derived from the broad surrounding platforms (Amapá and Pará-Maranhão).

As Marajó Rift became more mature in the Late Albian, the half-grabens have acquired a more symmetric configuration followed by cessation of faulting propagation and development of a major 

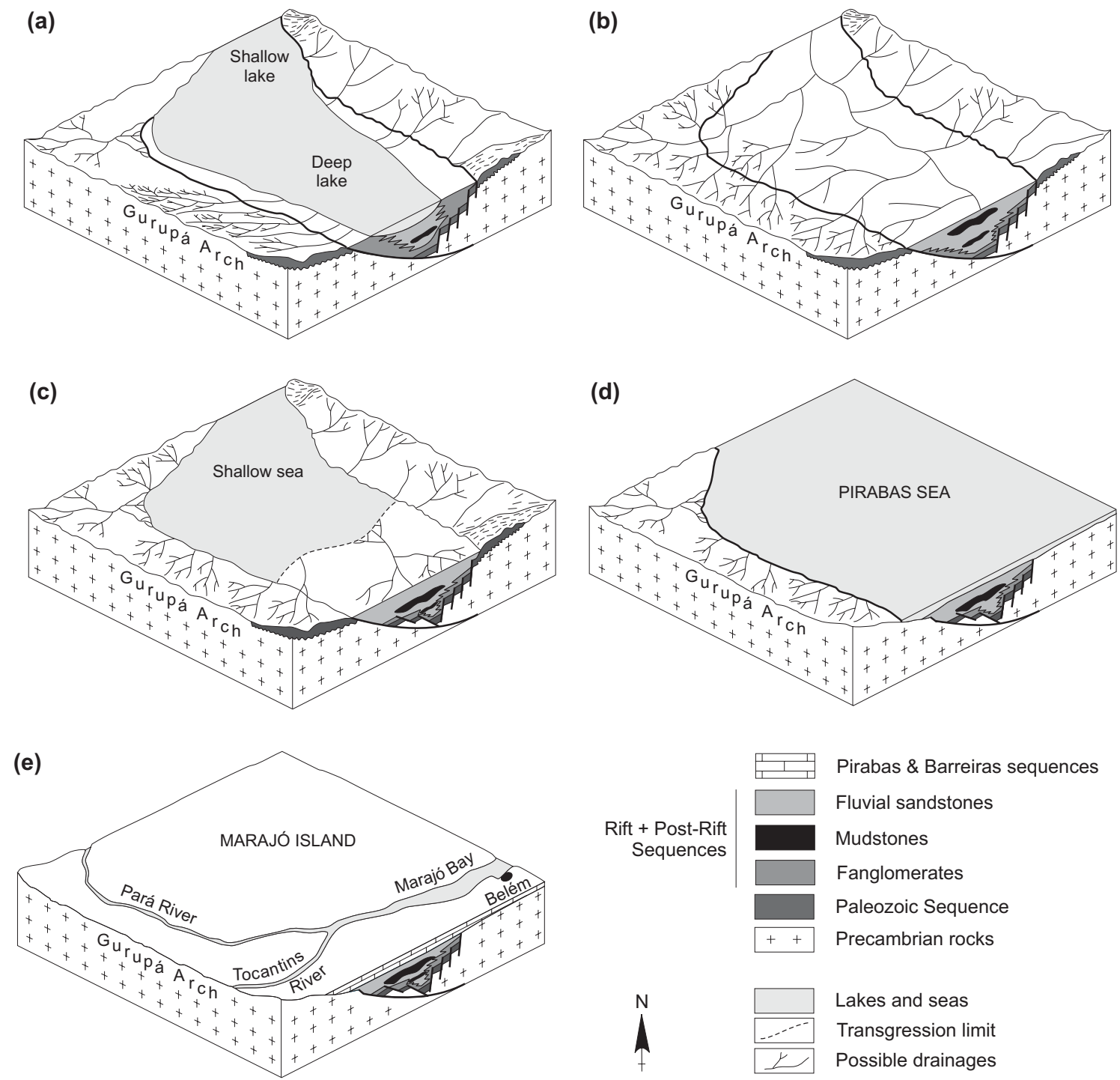

Fig. 5 - Four stages of the paleogeographic evolution of the Marajó region and surrounding areas. (a) Early-late Rift stage with the asymmetric depocenters being filled by fanglomerates derived greatly from the Gurupá Arch. (b) Later Rift stage characterized by a major fluvial system flowing into the Marajó Basin from west and southwest. (c) Post-rift stage defined by a more symmetric graben configuration with marine influence to the north. (d) Miocene-Pliocene physiography with the "Pirabas sea" incursion reaching 150 $\mathrm{km}$ in the continent. (e) Quaternary physiography largely characterized by fluvial-estuarine morphology.

unconformity that separates the Post-Rift Sequence from the Rift Sequence. The Post-Rift Sequence deposited from Maastrichtian times to the Early Oligocene, probably over an area of little physiographic variation since it is characterized by a fairly continuos package composed of fluvial and deltaic clastics which thickens to the north, where a marine influence is demonstrated by a brown shale interval in the basal Post-Rift Sequence of the Limoeiro and Mexiana sub-basins (Figure 5c). This interval represents Late Paleocene-Early Maastrichtian age marine sediments (Rezende and Ferradaes 1971, Schaller et al. 1971), and thins westward due to the sediment load of the Amazon River (Avenius 1988). 
The sediments supplied by the Tocantins River have been covered the southern Limoeiro, Mocajuba and Cametá sub-basins.

The Eocene marks another marine incursion in the Marajó Basin that reaches the northwestern Cametá Sub-Basin. In this sub-basin the transitional environment is evidenced from flaser structures and widespread bioturbed sediments, as well as black shales with high organic content derived probably from mangroves (Schaller et al. 1971). During the Eocene-Oligocene the major hydrographic basins of the Amazon region (Solimões, Madeira, Negro, Amazonas etc.) has flowed eastward due to the Andean uplifting. This suggests that the sediment loading of the Amazon drainage system has greatly affected the northwestern portion of the Marajó Basin since the Late Eocene.

In the Miocene-Pliocene much of the Marajó region and surrounded areas subsided in response to transtension linked to the dextral strike-slip regime of the neotectonic scenario. This led to marine incursion over large areas in the northern Brazil which is demonstrated by shallow water marine sequence (Pirabas Formation) followed by transitional sequence (Barreiras Group) exposed along the coast and underlain the Pleistocene deposits up to $150 \mathrm{~km}$ in the continent (Figure 5d).

The current landscape of the Marajó region and surrounded areas is characterized by fluvial deposits of the Amazon and Tocantins rivers greatly influenced by marine incursions. This fluvial-stuarine morphology is the result of the Tocantins River captured to the northeast and Marajó Island formation in the Late Pleistocene (Bemerguy 1997; Figure 5e).

\section{CONCLUSIONS}

The overall arcuate shape of the Marajó Rift and complex faulting geometry of the sub-basins are believed to be controlled by the combined weak zones of three distinct Precambrian orogenic belts. General trends and fault patterns of the Mocajuba, Cametá and Limoeiro sub-basins are strongly influenced by ductile thrusts and strike-slip shear zones within the Araguaia and Tumucumaque belts, while the trend and fault systems of the Mexiana SubBasin run parallel to the weakness zones of the Amapá Belt.

Regional tectonic and stratigraphic evidence suggests that the Marajó Rift has a half-graben architecture that developed as a result of Mesozoic extension and shearing. Several strike-slip faults segmented the basin into geometric distinct extensional compartments and controlled the stratigraphy along its axis. Some faults are always characterized by smaller pull-apart sub-basins along striking with the Mexiana Sub-Basin being attributed to the en echélon pattern within the Arari Zone. Therefore, Mocajuba, Cametá and Limoeiro sub-basins are primarily extensional while the Mexiana Sub-Basin is greatly transtensional.

The Rift Sequence developed in response to active rifting and was filled by continental clastic sediments derived chiefly from the Gurupá Arch. In contrast, the Post-Rift Sequence deposited during a large quiescence period and received fluvial and deltaic clastics with marine influence in the northwestern of the basin, throughout the Late Cretaceous-Early Oligocene.

Much of the current landscape is due to transtension linked to strike-slip faults, which derived chiefly from the Mesozoic strike-slip faults reactivation since Miocene.

\section{ACKNOWLEDGMENTS}

We are grateful to PETROBRAS that kindly provided the seismic lines, the Bouguer anomaly data and unpublished reports for this study and the Master Thesis of J.M. Cahuana Villegas supervised by J.B.S. Costa.

\section{RESUMO}

A área da Bacia do Marajó apresenta feições geológicas e geomorfológicas devidas principamente à distensão Mesozóica e à neotectônica pós-miocênica. O evento de distensão, com fases do Cretáceo Inferior e Superior, originou quatro sub-bacias que contituem a Bacia do Marajó, com uma espessa sequiência clástica continental mostrando influência marinha. Falhas normais NW e NNW 
e direcionais NE e ENE controlaram a geometria da bacia. A distensão, relacionada com a abertura do Atlântico Equatorial, propagou-se continente adentro ao longo de zonas de fraqueza crustal dos cinturões orogênicos pré-cambrianos Tumucumaque, Amapá e Araguaia. O evento neotectônico é um regime transcorrente que desenvolveu bacias transtensivas preenchidas por sedimentos marinhos rasos (Formação Pirabas) e seqüências transicionais (Grupo Barreiras) do Terciário Superior, seguidos por depósitos fluviais e seqüências transicionais do Quaternário, derivadas dos rios Amazoans e Tocantins e do estuário do Marajó. A paisagem atual tem morfologia tipicamente estuarina. A morfologia costeira apresenta escarpas em sequiências transicionais do Terciário Superior, enquanto no interior dominam elevações sustentadas por crosta laterítica do Pleistoceno Médio, aparadas por superfície erosiva a $70 \mathrm{~m}$. No leste da Ilha do Marajó são reconhecidas várias gerações de paleocanais com seqüências estuarinas associadas, enquanto no lado oeste predomina uma planície flúvio-marinha.

Palavras-chave: Bacia do Marajó, estrutura, evolução, paleogeografia, geomorfologia.

\section{REFERENCES}

Aguiar GA, Bahia RR and Rezende WM. 1966. Prospecções geológicas e geofísicas executadas pela Petrobras na Foz do Amazonas. Belém: Petrobras, Departamento de Exploração do Norte. Relatório Interno 584A, $15 \mathrm{p}$.

Avenius CG. 1988. Cronostratigraphic study of the post-rift/sin-rift unconformity, Marajó Rift system. Belém: Texaco/Canada Report, 6 p.

Bemerguy RL. 1997. Morfotectônica e evolução paleogeográfica da região da calha do Rio Amazonas. Belém: Universidade Federal do Pará. Tese de Doutoramento, $200 \mathrm{p}$.

Bemerguy RL and Costa JBS. 1991. Considerações sobre o sistema de drenagem da Amazônia e sua relação com o arcabouço tectono-estrutural. Belém: Boletim do Museu Paraense Emílio Goeldi. Série Ciências da Terra (3): 75-97.

Caputo MV. 1984. Stratigraphy, tectonics, paleoclimatology and paleogeography of northern basins of Brazil. Santa Barbara: University of California. PhD
Thesis, $583 \mathrm{p}$.

Carnes JB, Chou GT, Katz BJ, Lorenzetti E and SHIH TC. 1989.Exploration analysis of syn-rift section of Marajó Basin. Belém: Texaco/Canada. Report 89/109, 61 p.

Carvajal DA, Dorman JT, Kenck AR, Key CF, Miller CJ AND SPECHT TD. 1989. Final report of the third exploration phase, Marajó. Belém: Texaco/Canada. Report, $61 \mathrm{p}$.

Costa JBS and Hasui Y. 1997. Evolução geológica da Amazônia. In: Costa ML AND ANGÉLICA RS (Eds.), Contribuição à Geologia da Amazônia. Belém: SBG/ FINEP, p. 15-90.

Costa JBS, Bemerguy RL, Hasui Y, Borges MS, FerReira Junior CRP, Bezerra PEL, Costa ML AND FERNANDES JMG. 1996. Neotectônica da região amazônica: aspectos tectônicos, geomorfológicos e deposicionais. Belo Horizonte: UFMG. Geonomos 4: 23-44.

Hasui Y AND Costa JBS. 1990. O cinturão Araguaia: um novo enfoque estrutural-estratigráfico. In: CONGresso Brasileiro de Geologia, 36, 1990, Natal. Anais... Natal, SBG, 6: 2535-2543.

Hasui Y, Haralyi NLE and Costa JBS. 1993. Megaestruturação pré-cambriana do território brasileiro baseada em dados geofísicos e geológicos. São Paulo: UNESP. Geociências 12: 7-32.

Hasui Y, Haralyi NLE and Schobbenhaus C. 1984. Elementos geofísicos e geológicos da região amazônica: subsídios para o modelo geotectônico. In: Symposium Amazonico, 2, 1984, Manaus. Anais... Brasília: DNPM, p. 129-147.

João XSJ, Carvalho JM, Vale AG, Frizzo SJ and Martins RC. 1979. Projeto Sudoeste do Amapá. Belém: DNPM/CPRM. Relatório Final, 125 p.

Lana M And Milani EJ. 1987. Notas sobre a evolução estrutural da Bacia de Marajó. Belém: Petrobras/ Departamento de Exploração do Norte/Divisão de Interpretação. Relatório Interno, 18 p.

LARA ME. 1992. The architecture of a failed rift system: Marajó Basin, northern Brazil. Eos Trans Am Geophys Un (73): 563.

Lima HP. 1987. Notas sobre a análise estratigráfica da Bacia de Marajó. Belém, Petrobras/Departamento de Exploração do Norte/Divisão de Interpretação. Relatório Interno, $15 \mathrm{p}$. 
Lima MiC, Montalvão RMG, Issler RS, Oliveira A, Basei MAS, Araújo JFV and SiLVa GG. 1974. Geologia. In: Projeto RADAM, Levantamento de Recursos Naturais, Folhas NA/NB.22 (Macapá). Rio de Janeiro: DNPM, p. 3-120.

Ludwig G. 1964. Geology of the Marajó Basin. Rio de Janeiro: Petrobras/Departamento de Exploração/ Divisão de Exploração. Relatório Interno, 20 p.

Miller CJ AND Avenius CG. 1986. Interpretation: regional vibroseis and dynamite seismic survey, Marajó. Belém: Texaco/Canada. Report, 96 p.
Rezende WN AND FerRadaes JO. 1971. Integração geológica regional da bacia sedimentar da Foz do Amazonas. Belém: Petrobras/Departamento de Exploração. Relatório Interno, 27 p.

Schaller H, Vasconcelos DN and Castro JC. 1971. Estratigrafia preliminar da bacia sedimentar da Foz do Amazonas. In: Congresso Brasileiro de GeoLOGIA, 25, 1971, São Paulo. Anais... São Paulo: SBG, p. 3: 189-202.

Villegas JM. 1994. Geologia estrutural da Bacia de Marajó. Belém: Universidade Federal do Pará. Dissertação de Mestrado, 119 p. 